\title{
POSISI KOPI ROBUSTA INDONESIA DI PASAR JERMAN MENGGUNAKAN METODE LINEAR APPROXIMATE ALMOST IDEAL DEMAND SYSTEM
}

\author{
Sevi Oktafiana Fortunika ${ }^{1}$, Harianto ${ }^{2}$, dan Suharno ${ }^{3}$ \\ 1) Program Magister Sains Agribisnis, Sekolah Pascasarjana, Institut Pertanian Bogor \\ 2,3)Departemen Agribisnis, Fakultas Ekonomi dan Manajemen, Institut Pertanian Bogor \\ Jl. Kamper Wing 4 Level 5 Kampus IPB Dramaga, Indonesia \\ e-mail: ${ }^{1)}$ sevioktafianafortunika@gmail.com
}

(Diterima 1 Juli 2019/Revisi 22 Juli 2019/Disetujui 20 Agustus 2019)

\begin{abstract}
Indonesia is one of the top coffee producers in the world. The major markets for Indonesian coffee are European Union (EU), then Germany is the largest importing country. This research analyzed the position for Indonesian robusta coffee in Germany among Vietnam and India as the major producers of robusta coffee as Indonesia. The econometric model of the Linear Approximate Almost Ideal Demand System was used to estimate a position for Indonesian robusta coffee among its competitors. The analysis utilized timeseries data from 1996 to 2017. The results of the study showed that the main exporting countries, including Indonesia, tended to have lower import tariffs than other countries, not the main exporters. The demand for imported coffee beans was generally influenced by the prices of major exporters, but demand for imported roasted coffee was not affected by the prices of major importing countries. Indonesian coffee beans in the German market was elastic, while roasted coffee was inelastic. Indonesian coffee competed with Vietnam both for coffee beans and roasted coffee. The expenditure elasticity of Indonesian coffee beans was positive and Indonesian roasted coffee was negative.
\end{abstract}

Keywords: Germany, green beans, LA/AIDS, roasted coffee

\begin{abstract}
ABSTRAK
Indonesia merupakan salah satu negara produsen kopi tertinggi di dunia. Pasar utama untuk kopi Indonesia adalah Uni Eropa (UE), dimana Jerman adalah negara pengimpor terbesar. Penelitian ini menganalisis posisi kopi robusta Indonesia di pasar Jerman antara Vietnam dan India sebagai negara produksi utama kopi robusta seperti Indonesia. Model ekonometri Linear Approximate Almost Ideal Demand System (LA/AIDS) digunakan untuk melihat posisi kopi Indonesia di antara para pesaingnya. Penelitian ini menggunakan data time series dari tahun 1996 hingga 2017. Hasil penelitian menunjukkan bahwa negara eksportir utama, termasuk Indonesia, cenderung memiliki tarif impor lebih rendah dibandingkan negara bukan pengekspor utama. Permintaan impor kopi biji secara umum dipengaruhi oleh harga negara eksportir utama, namun permintaan impor kopi bubuk tidak dipengaruhi oleh harga negara importir utama. Kopi biji dan kopi bubuk Indonesia di pasar Jerman bersifat elastis, sedangkan kopi bubuk bersifat inelastis. Kopi Indonesia berkompetisisi dengan dengan Vietnam baik untuk kopi biji dan kopi bubuk. Elastisitas pengeluaran kopi biji Indonesia bernilai positif dan kopi bubuk Indonesia bernilai negatif.
\end{abstract}

Kata kunci: Jerman, kopi biji, kopi bubuk, LA/AIDS

\section{PENDAHULUAN}

Menurut Indonesia Eximbank dan UNIED (2019) memprediksikan bahwa dengan meningkatnya konsumsi kopi di pasar Internasional, maka konsumsi kopi di pasar dunia juga akan terus meningkat. Konsumsi kopi dunia sebanyak 165,19 juta kantong pada tahun 2018-2019, meningkat 2,1 persen dibandingkan dengan tahun 2017-2018. Konsumsi domestik di negara-negara pengekspor 
meningkat 1,4 persen menjadi 50,3 juta kantong dan konsumsi di negara-negara pengimpor juga naik 2,5 persen menjadi 114,88 juta kantong. Sementara pada tahun 2018-2019, produksi kopi dunia melebihi konsumsi sebesar 2,29 juta, sehingga menimbulkan persaingan yang tinggi antar negara pengekspor kopi.

Kopi ditanam dan diekspor oleh lebih dari 50 negara berkembang, sedangkan konsumen utama kopi ada di negara industri seperti Amerika Serikat, Eropa dan baru-baru ini, Jepang (DFID 2004). Secara global, kopi adalah komoditas perdagangan utama kedua setelah minyak dan dengan demikian memainkan peran penting dalam neraca perdagangan antara negara-negara maju dan berkembang.

Kopi menjadi salah satu komoditas ekspor utama perkebunan Indonesia (Kementan 2017). Produksi kopi Indonesia yang melimpah tersebut menjadikan Indonesia sebagai negara produsen kopi terbesar di dunia setelah Brazil, Vietnam dan Kolombia, dengan output produksi sebesar 654 ribu ton pada tahun 2017 atau sama dengan 6,84 persen dari produksi kopi dunia (ICO 2018).

Banyak peminat kopi dari mancanegara untuk mengonsumsi kopi Indonesia sehingga tujuan ekspor kopi Indonesia tersebar ke berbagai negara di dunia.. Saat ini, pengimpor kopi Indonesia terbesar di dunia adalah Eropa diikuti oleh Asia dan Amerika Serikat. Tahun 2013, ekspor kopi Indonesia ke Amerika Serikat sebesar 17.6 persen, ekspor ke Asia sebesar 24,3 persen dan ekspor ke Eropa sebesar 33.9 persen, dimana Jerman merupakan negara pengimpor kopi terbesar di Eropa.

Namun demikian, pangsa pasar kopi Indonesia tidak sebanding dengan besarnya nilai ekspor kopi Indonesia. Pangsa pasar kopi Indonesia di Amerika Serikat hanya sebesar 3.8 persen, bahkan di Eropa hanya 1 persen. Jika dibandingkan dengan total ekspor kopi dunia, Indonesia hanya mampu berperan kurang lebih sebesar 6 persen, dimana jumlah tersebut masih sangat sedikit (Trade Map 2018).
Selain kontribusi ekspor yang masih sedikit, harga ekspor kopi Indonesia juga tidak bisa bersaing dengan negara ekspor terbesar lainnya. Rata-rata harga kopi Indonesia hanya sebesar 2,4 US\$ $/ \mathrm{kg}$. Berdasarkan data dari Asosiasi Eksportir Kopi dan Industri Kopi Indonesia (AEKI), bahwa dari 4 jenis produk kopi yang diekspor oleh Indonesia, kopi biji memiliki nilai ekpor paling tinggi, yaitu 1.166.244.000 US\$ dengan volume ekspor 532.157. Namun demikian, harga ekspor kopi biji Indonesia rendah, yaitu hanya sebesar 2,2 US\$ $/ \mathrm{kg}$. Berbeda dengan harga kopi bubuk yang harganya mencapai 4,2 US\$/ kg namun volume ekspor hanya 1.867 ton (AEKI 2014). Artinya, dominasi ekspor kopi Indonesia berbentuk kopi biji yang masih bersifat raw material dengan harga masih rendah.

Selama tahun 2013-2017, CAGR (pertumbuhan majemuk per tahun) nilai ekspor kopi Indonesia ke negara importir utama tercatat positif, yaitu Amerika Serikat (5,5 persen), Malaysia (2,2 persen), Italia (0,8 persen). Namun CAGR nilai ekspor kopi tercatat negatif ke negara tujuan utama seperti Jerman (-3,9 persen). Bahkan data JanuariNovember 2018, nilai dan volume ekspor Kopi Indonesia turun, di level -33.97 persen. Hal ini disebabkan oleh peningkatan konsumsi kopi perkapita setiap tahunnya dari pasar domestik yang menyebabkan supply ekspor kopi Indonesia berkurang. Selain itu, meningkatnya harga kopi di pasar lokal dan melemahnya pasar kopi dunia juga menjadi faktor turunnya ekspor kopi Indonesia (Indonesia Eximbank dan UNIED 2019).

Menembus pasar internasioanl dengan jenis dan harga yang diinginkan tidaklah mudah tanpa suatu hambatan. Bukan hanya hambatan tarif, namun hambatan non tarif seperti problem kualitas dan standar mutu kopi juga salah satu faktor yang menghambat ekspor kopi Indonesia. Berbicara mengenai kualitas dan standar mutu tidak terlepas dari kemampuan komoditas yang berdaya saing, dengan adanya pengawasan mutu, maka beberapa kepentingan akan terpenuhi diantaranya kepentingan keselamatan, keamanan, kesehatan masyarakat serta pelestarian fungsi 
lingkungan, dimana kesemuanya merupakan output yang diharapkan dari pemberlakuan Non Tariff Measures (NTM).

Berdasarkan penelitian Purnamasari et al. (2014), Indonesia sebagai negara pengekspor kopi terbesar keempat di dunia belum memiliki keunggulan kompetitif. Namun secara general, kopi Indonesia memang tidak memiliki keunggulan kompetitif di pasar dunia, namun ada kemungkinan Indonesia mempunyai keunggulan komparatif atau keunggulan kompetitif pada pasar-pasar yang lebih spesifik, misalnya di suatu negara atau benua tertentu.

Menembus pasar Internasional bukanlah hal yang mudah. Terdapat kebijkan perdagangan yang harus dilewati oleh setiap eksportir, yaitu berupa kebijakan tarif dan non tarif. UNCTAD (2013) menyatakan bahwa pada kebijakan non tarif, Sanitary and Phytosanitary (SPS) dan Tehnical Barriers to Trade (TBT) paling banyak diterapkan oleh seluruh negara di dunia. SPS dan TBT sangatlah umum dilakukan dalam pemberlakuan regulasi perdagangan dengan menerapkan 15-30 persen dari produk perdagangan. Hal tersebut menimbulkan kekhawatiran bagi pihak eksportir, terutama eksportir dari negara berkembang.

Kebijakan-kebijakan ekspor yang diterapkan oleh negara-negara importir pada komoditi kopi mewajibkan Indonesia memperhatikan persyaratan tersebut untuk dipenuhi. Atas desakan negara importir sebagai konsumen, International Coffee Organization (ICO) telah menetapkan persyaratan mutu ekspor kopi. Isu kontaminasi Ochratoxin A (OTA) dan Carbaryl mengakibatkan daya saing kopi Indonesia melemah di pasar Internasional (Dradjat et al 2007; Kementan 2014; Nugroho 2014).

Berdasarkan penjelasan diatas, pemerintah selaku pengambil kebijakan menghadapi permasalah diantaranya (a) nilai ekspor yang cenderung mengalami perlambatan dari tahun ke tahun, (b) harga ekspor kopi yang belum bisa bersaing dengan harga kopi negara pengekspor lainnya, (c) keterbatasan ekspor kopi Indonesia yang masih didominasi oleh kopi biji (raw material) dikarenakan tarif impor dan standarisasi mutu yang tinggi.

Dilain hal, pemerintah menargetkan peningkatan volume ekspor biji kopi Indonesia pada tahun 2025 sebesar 24,3 persen atau sebesar 462,497 ton, yang merupakan bagian dari Rencana Pembangunan Jangka Panjang Nasional (Kementan 2015) dan peningkatan konsumsi per kapita sebesar 1,5 kg per tahun yang tercantum dalam Rencana Induk Pembangunan Industri Nasional (Kemenperin 2015).

Mengingat kopi merupakan pasar potensial, jika ekspor kopi meningkat, bukan hanya akan meningkatkan perekonomian secara makro, namun ekonomi mikro pedesaan juga akan meningkat, mengingat 95 persen tanaman kopi adalah perkebunan rakyat yang ditaman di daerah pedesaan. Masalah penyerapan tenaga kerja dan kemiskinan masyarakat pedesaan juga bisa diatasi melalui program pengembangan komoditas kopi. Selain itu, komoditas kopi menjadi terobosan penyedia lapangan pekerjaan dalam bidang industri dan perdagangan. Sehingga menjadi suatu hal yang penting melihat posisi kopi Indonesia di negara importir utama, salah satunya Jerman yang merupakan pasar potensial kopi Indonesia.

Penelitian ini memiliki tujuan (1) Menganalisis dinamika kebijakan perdagangan (tarif dan non tarif) ekspor kopi Indonesia (2) Menganalisis faktor-faktor yang mempengaruhi permintaan ekspor kopi Indonesia di pasar Jerman (3) Menganalisis posisi kopi Indonesia di pasar Jerman yang dipengaruhi oleh hambatan perdagangan.

Penelitian ini diharapkan dapat memberikan manfaat serta kontribusi kepada pertumbuhan perdagangan kopi Indonesia, terutama kepada pengembang dan pengedukasi petanipetani kecil (smallholders), dimana memiliki peranan penting dalam perkembangan perdagangan kopi Indonesia di dunia, terutama di pasar Jerman. 


\section{METODE}

\section{PENGUMPULAN DATA DAN ANALISIS}

Jenis data yang digunakan dalam penelitian ini adalah data primer dan data sekunder. Data primer diperoleh dengan cara wawancara dengan pihak-pihak yang terlibat dengan proses ekspor kopi, pakar kopi dan asosiasiasosiasi yang relevan dengan masalah ekspor kopi tersebut. Data sekunder terdiri dari data time series tahunan (tahun 1996-2017) yang diambil dari beberapa sumber sebagaimana ditulis pada Tabel 1 .

Tabel 1. Sumber Data

\begin{tabular}{ll}
\hline \multicolumn{1}{c}{ Jenis Data } & \multicolumn{1}{c}{ Sumber Data } \\
\hline $\begin{array}{l}\text { Jumlah dan harga } \\
\text { ekspor kopi }\end{array}$ & UN COMTRADE \\
$\begin{array}{l}\text { Nilai tukar dan GDP } \\
\text { per-kapita }\end{array}$ & WorldBank \\
$\begin{array}{l}\text { Kebijakan tarif } \\
\text { impor }\end{array}$ & $\begin{array}{l}\text { ITC (International } \\
\text { Trade Center) }\end{array}$ \\
$\begin{array}{l}\text { Kebijakan non tarif } \\
\text { impor: Sanitary and }\end{array}$ & $\begin{array}{l}\text { World Trade } \\
\text { Ohytosanitary (SPS) } \\
\text { dan TBT (Technical } \\
\text { Barier to Trade) }\end{array}$ \\
\hline
\end{tabular}

Penelitian ini membahas permintaan ekspor kopi robusta Indonesia di pasar Jerman, dibatasi pada analisis persaingan antara Indonesia, Vietnam dan India. Data yang digunakan adalah data sekunder berupa data impor kopi biji dan kopi bubuk di negara importir kopi dengan HS 090111 dan HS 090121.

Model analisis data Linear Approximate Almost Ideal Demand Systemd (LA/AIDS) digunakan untuk menganalisis posisi kopi Indonesia diantara dua negara ekspor utama kopi robusta, yaitu Indonesia, Vietnam dan India. Pemilihan negara tersebut didasarkan pada nilai pangsa ekspor yang terbesar dan stabil sepanjang tahun. Data-data tersebut kemudian akan diestimasi menggunakan model AIDS (1).

$$
\begin{aligned}
w_{\mathrm{i}}= & \alpha_{i}+\sum_{j=1}^{n} \gamma_{i j} \ln P_{j}+\beta_{i} \ln \left(\frac{x}{p_{*}}\right)+\theta_{i} \ln E R+ \\
& \lambda_{i} \ln G D P+\sigma_{i} \ln T f+f_{i} N T M+e \\
w_{\mathrm{v}}= & \alpha_{i}+\sum_{j=1}^{n} \gamma_{i} \ln P_{j}+\beta_{i} \ln \left(\frac{x}{p_{*}}\right)+\theta_{i} \ln E R+ \\
& \lambda_{i} \ln G D P+\sigma_{i} \ln T f+f_{i} N T M+e \\
w_{\mathrm{a}}= & \alpha_{i}+\sum_{j=1}^{n} \gamma_{i j} \ln P_{j}+\beta_{i} \ln \left(\frac{x}{p_{*}}\right)+\theta_{i} \ln E R+ \\
& \lambda_{i} \ln G D P+\sigma_{i} \ln T f+£_{i} N T M+e \ldots \ldots \ldots \ldots . .
\end{aligned}
$$

Dimana:

$\mathrm{W}_{\mathrm{i}} \quad$ : share ekspor kopi Indonesia di Jerman

$\mathrm{w}_{\mathrm{v}}$ : share ekspor kopi Vietnam di Jerman

$\mathrm{W}_{\mathrm{a}} \quad$ : share ekspor kopi India di Jerman

$\mathrm{p} \quad$ : harga kopi negara eksportir (US\$/ton)

$\mathrm{x} \quad$ : total nilai impor (ton)

$\mathrm{p}^{*} \quad$ : indeks harga geometrik Stone $\sum w i \cdot p i$

$E R \quad$ : nilai tukar riil

GDP : Gross Domestic Product (US\$)

Tf : Tarif (US\$)

NTM : Non Tariff Measures atau non tarif impor (dengan frecuency index)

e : Galat

Metode Linear Almost Ideal Demand System (LA/AIDS) digunakan untuk melihat posisi kopi Indonesia yang dipengaruhi oleh variabel kebijakan perdagangan seperti hambatan tarif dan non tarif merupakan kebaruan dalam penelitian ini, dimana sebelumnya metode LA/AIDS hanya dipakai untuk menganalisis permintaan pada perdagangan internasional tanpa melihat faktor kebijakan perdagangan. Selain itu, penelitian ini juga memiliki kebaruan melalui penggunaan frecuency index untuk mengkuantitatifkan variabel non tarif, yang selanjutnya dimasukkan dalam model LA/AIDS.

Penelitian terdahulu seperti Deaton dan Muellbauer (1980) pertama kali menemukan metode analisis permintaan suatu produk dengan metode AIDS. Berdasarkan model AIDS, harga merupakan jembatan yang menghubungkan antara sisi permintaan dan penawaran.

Penelitian Galarraga dan Markandya (2004) pada studi kasus fair trade dan kopi 
organik di United Kingdom (UK) telah menguji bahwa metode Almost Ideal Demand System (AIDS) dapat mengestimasi permintaan untuk produk berkelanjutan. Selanjutnya Rifin (2010) Gebrehiwot dan Daloonpate (2012); Li dan Jung (2014); Yohannes dan Matsuda (2016); di berbagai topik perdagangan Internasional.

Suherman (2016) dan Simanjuntak (2017) juga menggunakan model LA/AIDS untuk menganalisis permintaan kaitannya dengan ekspor-impor Indonesia. Jamil (2015) dalam penelitiannya menggunakan AIDS untuk menganalisis permintaan impor garam Indonesia dengan pendekatan estimasi elastisitas permintaan garam di Indonesia. Sementara itu, Syaffendi et al (2013) mengidentifikasi daya saing karet alam Indonesia diantara negara-negara produsen karet alam lainnya di pasar Tiongkok.

Seiring dengan pengembangan studi penelitian, terdapat penyempurnaan model AIDS seperti perubahan model statis menjadi model dinamis melalui teknik error correction yang diajukan oleh Engle dan Grenger (Wan et al 2010) atau penelitian Eakins (2003) mengaplikasikan model AIDS secara dinamis dan dilakukan dengan penggunaan data time series. Beberapa penelitian juga memasukkan variable dummy sebagai variable pelengkap model.

Penelitian ini menggunakan variabel dummy kebijakan non tarif (SPS dan TBT) yang dihitung dengan rumus frequency index. Fugazza (2013) menjelaskan bahwa frequency index dapat digunakan untuk mengukur ada atau tidaknya suatu hambatan non tarif dan merangkum persentase produk atas kebijakan yang diterapkan. Perhitungan tersebut dapat dirumuskan pada persamaan (2).

$F_{i j t}=\left[\frac{\sum(\mathrm{Dk} t \mathrm{x} \mathrm{Mkt})}{\sum \mathrm{Mkt}}\right] \times 100$

Dimana :

$F_{i j t}$ : Frequency index eksportir i ke importir j pada tahun $\mathrm{t}(\%)$
$\mathrm{D}_{\mathrm{kt}}$ : Variabel dummy yang menunjukkan ada atau tidaknya kebijakan non tariff pada produk $\mathrm{k}$ pada tahun $\mathrm{t}$

$\mathrm{M}_{\mathrm{kt}}$ : Jumlah produk $\mathrm{k}$ dengan total tahun dari jumlah yang diimpor

Dari parameter-parameter AIDS yang telah diestimasi ditentukan nilai elastisitasnya untuk menggambarkan tingkat persaingan antar negara. Nilai-nilai elastisitas tersebut yaitu: (3) elastisitas harga sendiri, (4) elastisitas harga silang, dan (5) elastisitas pengeluaran. Elastisitas-elastisitas tersebut dihitung berdasarkan rumus sebagai berikut:

Elastisitas Harga Sendiri

$e_{i j}=\frac{\left(\hat{\mathrm{y}}_{i j}-\beta_{i} w_{i}\right)}{\dot{\mathrm{w}}_{i}}-1$

Elastisitas Harga Silang

$e_{i j}=\frac{\left(\hat{\mathrm{y}}_{i j}-\beta_{i} w_{j}\right)}{\dot{\mathrm{w}}_{i}} ; i \neq j$

Expenditure elasticity

$\eta_{i}=1+\frac{\beta_{i}}{\dot{\mathrm{w}}_{i}}$

Dimana,

$\hat{y}_{i j}$ : parameter harga barang $\mathrm{i}$ di pasar $\mathrm{j}$

$\beta_{i}$ : total nilai impor barang i di pasar $\mathrm{j}$

$w_{i}$ : share barang $\mathrm{i}$

$w_{j}$ : share barang $\mathrm{j}$

\section{HASIL DAN PEMBAHASAN}

\section{DINAMIKA EKSPOR KOPI INDONESIA DAN PASAR INTERNASIONAL}

Ekspor kopi Indonesia tidak terlepas dari hambatan kebijakan tarif dan non tarif atau Non Tariff Measures (NTMs) yang diterapkan oleh masing-masing negara. Terdapat perbedaan yang signifikan antara tarif impor kopi biji dan kopi bubuk di Jerman. Apabila dilihat dari data tarif impor di Jerman mulai tahun 1996, tarif impor kopi biji di negara tersebut masih memberlakukan, sampai akhirnya pada tahun 2000, tarif impor untuk kopi biji di Jerman dihapuskan. Berbeda dengan kopi bubuk, tarif impor kopi bubuk 


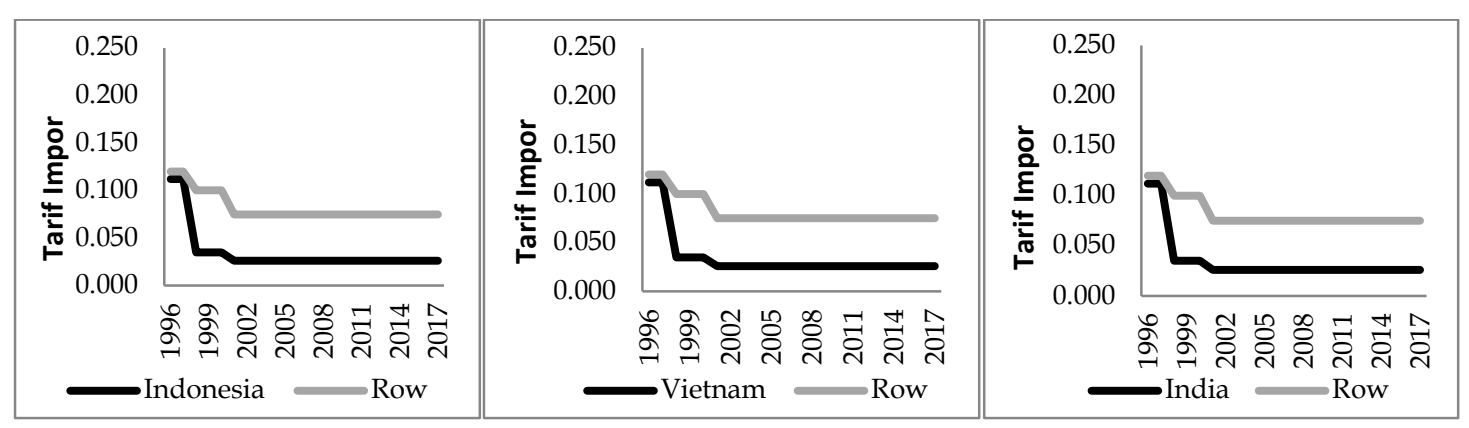

Gambar 1. Tarif Impor Kopi Bubuk Negara Eksportir Utama Tahun 1996-2017 Sumber: ITC (International Trade Center), diolah

cenderung lebih tinggi dibandingkan dengan tarif impor kopi biji, hingga saat ini Jerman masih memberlakukan tarif impor untuk kopi bubuk yang relatif tinggi.

Tarif impor untuk negara exportir utama termasuk Indonesia, Vietnam dan India cenderung lebih rendah dibandingakan dengan negara bukan exportir utama. Jika dilihat dari keberpihakan tarif impor antar dua negara, Jerman memberlakukan tarif impor yang sama untuk Indonesia, Vietnam atupun India. Berbeda dengan negara lain seperti Jepang yang cenderung memberlakukan tarif impor yang rendah terhadap Vietnam. Sejak tahun 1998, Jerman menurunkan tarif impor kopi bubuk dari 11,5 persen menjadi 3,5 persen, kemudian tahun 2001 diturunkan kembali menjadi 2,6 persen hingga sekarang. Secara umum, prosentase tarif impor yang dikenakan untuk kopi bubuk lebih tinggi dibandingkan prosentase tarif impor untuk kopi biji. Penjelasan tarif impor kopi bubuk secara rinci ditampilkan pada Gambar 1.

Non Tariff Measures (NTM) juga diterapkan di berbagai negara untuk melindungi produsen domestik dari produsen luar negeri dan konsumen dari berbagai wabah penyakit. Dengan adanya NTM, pemerintah Indonesia perlu memperhatikan berbagai kebijakan non tarif yang diterapkan oleh negara pengimpor terutama Sanitary and Phytosanitary (SPS) dan Technical Barrier to Trade (TBT).

Menurut Darhyati (2017), kebijakan SPS dan TBT yang diterapkan oleh negara maju lebih ketat dibandingkan dengan negara berkembang. Adanya peningkatan pendapatan dan kemakmuran yang lebih besar cenderung meningkatkan keamanan pangan sehingga permintaan produk akan keamanan pangan akan meningkat. Untuk menjaga keamanan pangan, negara maju menerapkan kebijakan yang lebih ketat seperti SPS dan TBT.

Dalam hal penerapan kebijakan non tarif, pemerintah Jerman lebih fokus menerapkan kebijakan SPS dibanding dengan kebijakan TBT. Hal ini dibuktikan berdasarkan data dari World Trade Organization bahwa pemerintah Jerman hanya menerapkan kebijakan SPS tanpa menerapkan kebijakan TBT.

Data kebijakan non tarif pada penelitian ini dihitung menggunakan pendekatan inventory dengan rumus frecuency index. Hasil perhitungan tersebut adalah sebagai berikut:

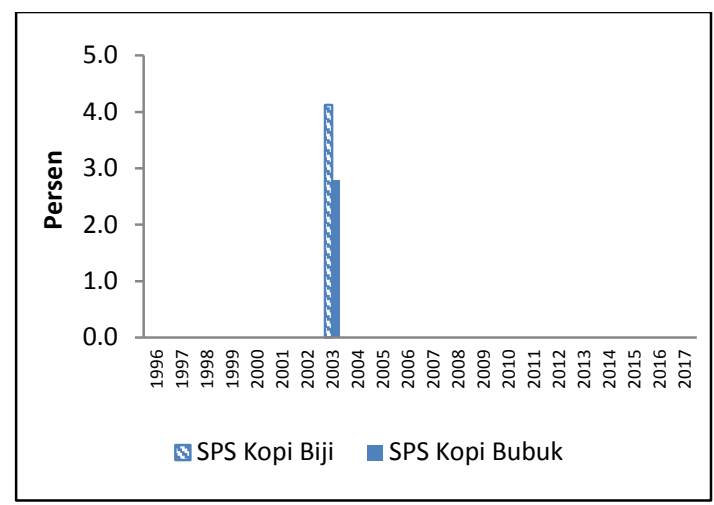
Gambar 2. Hasil Frequency Index SPS
Negara Jerman Tahun 1996-2017

Gambar 2 menunjukkan bahwa hasil perhitungan Frequency Index kebijakan SPS pada tahun 2003 sebesar 4 persen untuk kopi kopi dan 3 persen untuk kopi bubuk. Kebijakan ini hanya diterapkan satu kali di tahun tersebut, tahun selanjutnya Jerman tidak memberlakukan kembali kebijakan non tarif diatas. 
Impor kopi di Jerman merupakan suatu kegiatan yang penting. Jerman banyak mengimpor kopi dalam bentuk raw material dan kemudian diolah menjadi kopi bubuk atau produk yang siap dikonsumsi. Dapat dilihat bahwa Jerman selain menjadi negara pengimpor kopi terbesar, Jerman juga merupakan negara pengespor kopi yang besar pula. Oleh karena itu, demi kebutuhan perdagangan, Jerman tidak terlalu fokus pada kebijakan perdagangan termasuk non tarif ini. Jerman hanya menerapkan kebijakan SPS (Sanitary and Phytosanitary) seperti penetapan maksimum kandungan mikotoksin (Ochratoxin A, Deoxynivalenol, Zearalenone, dan Fumonisins).

Pemberlakuan NTMs khususnya SPS dan TBT dilakukan sebagai tindakan proteksi perdagangan pada suatu negara. SPS merupakan kebijakan yang diaplikasikan untuk melindungi kehidupan manusia, hewan, atau tumbuhan, serta kesehatan dan lingkungan. Sedangkan TBT diterapkan untuk menangani regulasi teknis dan prosedur penilaian kesesuaian seperti peningkatan kualitas, pengemasan, pelabelan, dan standar suatu produk. (UNCTAD 2013). Hasil model menunjukkan bahwa kebijakan SPS dan TBT masih menjadi pengaruh yang negatif terhadap ekspor kopi Indonesia, terutama untuk produk turunan seperti kopi bubuk Indonesia, seperti pada penelitian (Fortunika et al., 2021). Hal tersebut karena adanya keperluan pengecekan serta prosedur sertifikasi yang berpengaruh pada peningkatan biaya yang harus ditanggung oleh produsen.

Namun studi yang dilakukan oleh Chen et al (2008) memberikan hasil bahwa standar kualitas dan pelabelan memiliki dampak positif pada volume dan cakupan ekspor. Adanya dampak positif disebabkan karena peningkatan standar kualitas telah mengurangi ketidakpastian dan meningkatkan willingness to pay konsumen.

\section{FAKTOR-FAKTOR YANG MEMPENGARUHI EKSPOR KOPI INDONESIA}

Hasil estimasi dari model AIDS juga digunakan untuk menganalisis faktor-faktor yang mempengaruhi permintaan kopi Indonesia di pasar Jerman. Terdapat beberapa variabel bebas pada model, diantaranya variabel harga kopi Indonesia, harga kopi Vietnam, harga kopi India, harga kopi row, total nilai impor, Gross Domestic Product (GDP) per-kapita, nilai tukar riil, tarif impor dan variabel non-tarif. Variabel non-tarif di pasar Jerman hanya ada Sanitary and Phytosanitary (SPS) sedangkan dan Technical Barier to Trade (TBT) di Jerman tidak ada, sehingga pada penelitian ini hanya varibael SPS yang dimasukkan sebagai variabel non tarif. Sama seperti pembahasan sebelumnya, variabel non-tarif ini dianalisis dengan pendekatan inventory yaitu dengan frequency index.

Sebelum membahas faktor-faktor yang mempengaruhi ekspor kopi Indonesia, akan ditampilkan tabel proporsi ekspor kopi Indonesia dan negara eksportir utama lainnya ke pasar Jerman (Tabel 2). Berdasarkan tabel tersebut, pangsa kopi biji Indonesia di Jerman, selama 22 tahun terakhir secara hanya sebesar 4,2002 persen. Sedangkan proporsi ekspor kopi bubuk Indonesia ke Jerman hanya sebesar 0,0425 persen. Proporsi ini sangat kecil jika dibandingkan dengan pangsa impor kopi biji Vietnam. Kecilnya share tersebut juga terjadi pada ekspor kopi bubuk negara eksportir utama. Bahkan semua negara ekportir kopi utama tersebut memiliki share impor kopi bubuk kurang dari 1 persen. Hasil ini menunjukkan bahwa Jerman banyak mengimpor kopi dalam bentuk kopi biji. Walaupun Jerman merupakan negara pengimpor sekaligus pengekspor kopi, namun Jerman lebih cenderung sebagai negara pengimpor dibandingkan negara pengekspor kopi (Kemendag 2015). 
Tabel 2. Share Kopi di Negara Importir Utama Tahun 1996-2017

\begin{tabular}{lcr}
\hline Negara Impotir & $\begin{array}{c}\text { Kopi } \\
\text { Biji }\end{array}$ & $\begin{array}{c}\text { Kopi } \\
\text { Bubuk }\end{array}$ \\
\hline Indonesia & 4,2002 & 0,0425 \\
Vietnam & 10,8636 & 0,0129 \\
India & 2,2270 & 0,2330 \\
\hline
\end{tabular}

Hasil estimasi dari model AIDS juga digunakan untuk menganalisis faktor-faktor yang mempengaruhi permintaan kopi Indonesia di pasar Jerman. Terdapat beberapa variabel bebas kopi biji yang signifikan pada model, diantaranya variabel harga Indonesia, harga Vietnam, harga India, total nilai impor dan Gross Domestic Product (GDP) per-kapita. Sedangkan variabel bebas kopi bubuk yang signifikan pada model adalah variabel harga rest of the world (row), total nilai impor dan Gross Domestic Product (GDP) perkapita, nilai tukar riil dan tarif impor. Secara lebih rinci, faktor-faktor yang mempengaruhi permintaan ekspor kopi Indonesia ditampilkan pada Tabel 3.

Tabel 3. Hasil Estimasi Model LA/AIDS Kopi Bubuk Indonesia di Jerman

\begin{tabular}{|c|c|c|}
\hline \multirow[b]{2}{*}{ Variabel } & \multicolumn{2}{|c|}{ Jenis Kopi } \\
\hline & Kopi Biji & $\begin{array}{c}\text { Kopi } \\
\text { Bubuk }\end{array}$ \\
\hline Harga Kopi Indonesia & $-0,09693^{\star \star *}$ & 0,00005 \\
\hline Harga Kopi Vietnam & $0,07583^{* * *}$ & 0,00005 \\
\hline Harga Kopi India & $0,02110^{* *}$ & $-0,00010$ \\
\hline $\begin{array}{l}\text { Harga kopi Rest of } \\
\text { The World }\end{array}$ & $-0,00025$ & $-0,00135^{* * *}$ \\
\hline Total Nilai Impor & $0,09251^{* * *}$ & $-0,00107^{\star \star *}$ \\
\hline $\begin{array}{l}\text { Gross Domestic } \\
\text { Product Per-Kapita }\end{array}$ & $-0,12029^{* *}$ & $0,00396^{* * *}$ \\
\hline Nilai Tukar Riil & $-0,00288$ & $-0,00028^{* * *}$ \\
\hline Tarif Impor & 0,00020 & $0,00013^{* * *}$ \\
\hline Non tarif impor & $-0,06322$ & - \\
\hline Konstanta & $-0,61113$ & $-0,02557$ \\
\hline R-Square & $39,11^{\text {*** }}$ & $89,75^{\text {** }}$ \\
\hline $\begin{array}{r}\text { an: }{ }^{*)} \text { nyata } p \\
\\
{ }^{* *} \text { nyata } p \\
\\
\text { (**) nyata }\end{array}$ & $\begin{array}{l}\text { af } 1 \text { perse } \\
\text { af } 5 \text { perse } \\
\text { raf } 10 \text { per }\end{array}$ & $\begin{array}{l}\text { ), } \\
\text { 5), } \\
10) .\end{array}$ \\
\hline
\end{tabular}

Berdasarkan hasil estimasi model, variabel harga kopi Indonesia untuk kopi biji signifikan pada taraf nyata 1 persen (Tabel 3), artinya variabel tersebut berpengaruh nyata terhadap proporsi (pangsa) impor kopi biji Indonesia di Jerman. Koefisien yang didapatkan untuk variabel harga kopi biji Indonesia adalah $-0,09693$, maka setiap harga kopi biji Indonesia naik 1 persen, maka proporsi (pangsa) impor kopi biji Indonesia di Jerman akan turun sebesar 0,09693 persen (ceteris paribus). Hasil ini menunjukkan bahwa harga kopi biji Indonesia memiliki pengaruh negatif terhadap proporsi (pangsa) impor kopi biji Indonesia di pasar Jerman. Nilai koefisien dengan tanda yang negatif sesuai dengan hukum permintaan, yaitu jika harga naik, maka permintaan terhadap barang tersebut akan turun, atau sebaliknya. Ketika harga kopi biji Indonesia naik, maka Jerman akan cenderung mengimpor kopi biji dari negara lain. Hasil ini sesuai dengan penelitian (Baroh dan Istis et al, 2014).

Faktor harga yang mempengaruhi permintaan kopi biji Indonesia di Jerman lainnya selain harga kopi biji Indonesia adalah harga kopi Vietnam dan harga kopi India. Penjelasan tersebut menunjukkan bahwa harga negara eksportir utama mempengaruhi proporsi impor kopi Jerman, bukan dipengaruhi oleh negara eksportir lainnya (row).

Faktor-faktor yang mempengaruhi permintaan kopi bubuk Indonesia di Jerman juga ditunjukkan pada Tabel 3. Berdasarkan tabel diatas, nilai koefisien variabel harga kopi biji dan kopi bubuk Indonesia menunjukkan tanda positif dan negatif yaitu sebesar $-0,09693$ untuk kopi biji dan 0,00005 untuk kopi bubuk. Artinya, apabila harga kopi biji Indonesia naik, maka proporsi (pangsa) impor kopi biji Indonesia di Jerman akan turun, namun jika kopi bubuk Indonesia naik, maka proporsi (pangsa) impor kopi bubuk Indonesia di Jerman justru akan naik. Namun demikian, koefisien harga kopi bubuk Indonesia tidak signifikan, sehingga variabel tersebut tidak berpengaruh secara nyata terhadap proporsi impor kopi Indonesia.

Berbeda dengan kopi biji, faktor harga yang mempengaruhi permintaan kopi bubuk Indonesia di Jerman hanya harga kopi rest of the world. Penjelasan tersebut menunjukkan bahwa harga kopi bubuk negara eksportir 
utama tidak mempengaruhi proporsi impor kopi Jerman, melainkan dipengaruhi oleh negara eksportir selain Indonesia, Vietnam dan India.

Koefisien variabel GDP per-kapita (gdp) kopi biji sebesar -0,12029 dan variabel GDP per-kapita (gdp) kopi bubuk sebesar 0,00396. Kedua variabel tersebut memiliki tanda yang berbeda, artinya kedua variabel tersebut memiliki pengaruh yang berbeda pula terhadap proporsi (pangsa) impor antara kopi biji maupun kopi bubuk Indonesia. Apabila GDP per-kapita negara Jerman mengalami kenaikan sebesar 1 persen, maka proporsi (pangsa) impor kopi biji Indonesia di Jerman akan turun sebesar 0,12029 persen, namun untuk proporsi (pangsa) impor kopi bubuk Indonesia di Jerman justru akan naik sebesar 0,00396 persen. Hasil ini menunjukkan bahwa ketika GDP Jerman naik, Jerman lebih memilih untuk mengimpor kopi dalam bentuk bubuk dari negara lain.

Koefisien variabel yang bernilai negatif juga terjadi pada variabel nilai tukar riil dan tarif impor. Berdasarkan penjelasan tersebut, dapat disimpulkan bahwa semakin tinggi nilai tukar riil mata uang Jerman terhadap Indonesia, maka akan semakin rendah proporsi (pangsa) impor kopi biji dan kopi bubuk Indonesia di Jerman. Begitu juga untuk tarif dan non tarif impor, ketika tarif dan non tarif impor dinaikkan, maka permintaan impor negara Jerman dari Indonesia akan turun. Hasil tersebut menunjukkan bahwa tarif impor merupakan salah satu hambatan perdagangan internasional.

Secara umum, hasil estimasi model AIDS kopi biji dan kopi bubuk Indonesia di pasar Jerman seperti ditampilkan pada Tabel 3 tersebut menunjukkan bahwa nilai $R$-square di pasar Jerman untuk kopi biji dan kopi bubuk secara berturut-turut sebesar 39,11 dan 89,75. Nilai ini memiliki arti bahwa keragaman proporsi (pangsa) impor kopi biji dari Indonesia di pasar Jerman dapat dijelaskan oleh variabel bebas yang terdapat pada model sebesar 39,11 persen untuk kopi biji, sedangkan sisanya 60,88 persen dijelaskan oleh variabel bebas lain diluar model dan 89,75 persen untuk kopi bubuk, sedangkan sisanya 10,25 persen dijelaskan oleh variabel bebas lain diluar model.

Nilai $R$-square kopi bubuk tersebut cukup tinggi. Nilai $p$-value F statistik yang didapatkan dari estimasi model AIDS juga menunjukkan hasil yang sangat baik. Nilai p-value $\mathrm{F}$ statistik yang diperoleh dari hasil estimasi model untuk kopi biji atau kopi bubuk di pasar Jerman signifikan pada taraf nyata 1 persen. Nilai ini memiliki arti bahwa variabel bebas secara bersama-sama dapat menjelaskan variabel terikatnya, yaitu variabel proporsi (pangsa) impor kopi biji dan kopi bubuk dari Indonesia di pasar Jerman.

\section{POSISI KOPI INDONESIA DIANTARA NEGARA EKSORTIR UTAMA KOPI ROBUSTA}

Posisi kopi Indonesia di pasar Jerman dapat diketahui berdasarkan tingkat kepekaan impor kopi Indonesia terhadap perubahan harga kopi Indonesia, maupun perubahan harga kopi negara eksportir utama lainnya seperti Vietnam dan India. Posisi kopi Indonesia juga ditentukan oleh sensitifitas ekspor kopi Indonesia terhadap pengeluaran total impor kopi negara tersebut. Elastisitas permintaan pada penelitian ini menggunakan elastisitas permintaan Marshallian (uncompensated) yang terdiri dari elastisitas harga sendiri, elastisitas harga silang dan elastisitas pengeluaran. Berikut tingkat kepekaan (elastisitas) dari suatu komoditas yang diminta terhadap perubahan harga.

Tabel 4. Hasil Elastisitas Harga Sendiri Kopi Indonesia

\begin{tabular}{lcc}
\hline \multicolumn{1}{c}{ Negara } & \multicolumn{2}{c}{ Elastisitas Sendiri } \\
\cline { 2 - 3 } Eksportir & Kopi Biji & Kopi Bubuk \\
\hline Indonesia & $-3,400$ & $-0,878$ \\
Vietnam & $-1,795$ & $-0,860$ \\
India & $-1,293$ & $-0,858$ \\
\hline
\end{tabular}

Sesuai dengan hasil elastisitas harga sendiri yang ditunjukkan pada Tabel 6, kopi biji Indonesia, Vietnam dan India bersifat elastis. Nilai elastisitas $-3,400$ pada kopi biji Indonesia di Jerman memiliki arti bahwa ketika harga 
kopi biji Indonesia naik sebesar 1 persen maka permintaan impor kopi biji Indonesia di Jerman turun sebesar 3,400 persen. Nilai elastisitas harga kopi biji Indonesia memiliki nilai yang cukup tinggi diantara negara lainnya, artinya bahwa kopi biji Indonesia memiliki tingkat kepekaan yang tinggi terhadap perubahan harga.

Tabel 4 juga menunjukkan bahwa diantara ketiga negara pengekspor kopi biji di Jerman, India merupakan negara yang memiliki nilai elastisitas harga sendiri terendah diantara negara lainnya, yaitu sebesar -1,293. Nilai elastisitas tersebut menunjukkan bahwa ketika terjadi kenaikan harga kopi biji dari India sebesar 1 persen maka akan menurunkan permintaan impor kopi biji India di Jerman sebesar 1,293 persen. Walupun nilai elastisitas ini adalah nilai elastisitas yang paling rendah, namun masih tergolong elastis.

Nilai elastisitas kopi bubuk Indonesia lebih rendah daripada elastisitas harga sendiri kopi biji. Nilai elastisitas $-0,878$ pada kopi bubuk Indonesia di Jerman memiliki arti bahwa ketika terjadi kenaikan harga kopi bubuk dari Indonesia sebesar 1 persen maka akan menurunkan permintaan impor kopi bubuk Indonesia di Jerman sebesar 0,878 persen.

Penjelasan diatas dapat dikatakan bahwa kopi biji Indonesia lebih elastis dibandingkan kopi bubuk Indonesia di pasar Jerman. Hasil ini menunjukkan bahwa persaingan kopi biji jauh lebih tinggi daripada kopi bubuk, sehingga sedikit saja terjadi perubahan harga, maka permintaan kopi biji akan berubah.

Secara umum, kopi biji disemua negara eksportir utama, yaitu Indonesia, Vietnam dan India bersifat elastis sedangkan kopi bubuk bersifat inelastis. Artinya, berapapun harga yang dinaikkan pada kopi bubuk tidak terlalu berpengaruh terhadap permintaan impor Jerman, namun jika harga kopi biji yang dinaikkan, maka akan berpengaruh terhadap permintaan impor kopi di Jerman.

Menurut Kemendag (2014), komoditas kopi yang diimpor oleh importir memiliki berbagai jalur distribusi, tergantung pada jenis produk yang diimpor. Untuk produk kopi bubuk atau kopi instan, importir dapat langsung menjual kepada konsumen, namun untuk kopi biji, umumnya importir akan mendistribusikan produk impor kepada pedagang besar atau wholesalers terlebih dahulu, kemudian didistribusikan kepada mass retailers, coffee roasters dan sebagainya. Dengan sedikitnya rantai distribusi pada kopi bubuk tersebut menyebabkan kenaiakan harga tidak berpengaruh terhadap share permintaan impor kopi dari Indonesia.

Selain elastisitas harga senidiri, posisi kopi Indonesia juga dilihat dari elastisitas harga silang, sesuai dengan Tabel 5. Jika dilihat dari nilai elastisitas harga silang, secara umum kopi biji Indonesia dengan Vietnam dan India berkompetisis atau bersifat subtitusi satu dengan lainnya.

Tabel 5. Hasil Elastisitas Harga Silang Kopi Biji Indonesia

\begin{tabular}{lccc}
\hline & \multicolumn{3}{c}{ Elastisitas Silang } \\
\cline { 2 - 4 } & Indo & Viet & India \\
\hline Indonesia & & 1,566 & 0,453 \\
Vietnam & 6,897 & & $-1,234$ \\
India & 1,087 & $-0,221$ & \\
\hline
\end{tabular}

Nilai 6,897 pada elastisitas silang di Jerman antara Indonesia dengan Vietnam memiliki arti bahwa ketika harga kopi biji dari Indonesia naik sebesar 1 persen maka akan permintaan kopi biji Vietnam naik sebesar 6,897 persen. Kopi biji Vietnam juga memiliki hubungan substitusi dengan Indonesia. Nilai elastisitas 1,566 pada elastisitas harga silang antara Vietnam dengan Indonesia memiliki arti bahwa ketika harga kopi biji dari Vietnam naik sebesar 1 persen maka pangsa impor kopi biji Indonesia naik sebesar 1,566 persen. Begitu juga dengan India, kenaikan harga negara Indonesia berpengaruh positif terhadap permintaan India dan sebaliknya.

Berbeda dengan India dan Vietnam, kedua negara tersebut saling melengkapi. atau memiliki hubungan komplementer. Nilai -0,221 pada elastisitas harga silang India dengan Vietnam menunjukkan apabila terjadi kenaikan harga kopi biji dari India sebesar 1 persen, maka kopi biji Vietnam turun sebesar 0,221 persen. Begitu juga Vietnam dengan India. 
Tabel 6 menunjukkan nilai elastisitas harga silang untuk kopi bubuk Indonesia. Kopi bubuk Indonesia di Jerman memiliki hubungan subtitusi dengan Vietnam namun komplementer dengan India.

Tabel 6. Hasil Elastisitas Harga Silang Kopi Bubuk Indonesia

\begin{tabular}{lccc}
\hline & \multicolumn{3}{c}{ Elastisitas Silang } \\
\cline { 2 - 4 } & Indo & Viet & India \\
\hline Indonesia & & 0,108 & $-0,223$ \\
Vietnam & 0,352 & & $-1,755$ \\
India & $-0,041$ & $-0,097$ & \\
\hline
\end{tabular}

Nilai 0,108 pada elastisitas silang kopi bubuk antara Indonesia dengan Vietnam memiliki arti bahwa ketika terjadi kenaikan harga kopi bubuk dari Indonesia sebesar 1 persen maka akan menaikkkan permintaan impor kopi bubuk Vietnam sebesar 0,108 persen. Sebaliknya, kopi bubuk Vietnam juga memiliki hubungan substitusi dengan Indonesia. Nilai elastisitas 0,352 pada elastisitas harga silang antara Vietnam dengan Indonesia memiliki arti bahwa ketika terjadi kenaikan harga kopi bubuk dari Vietnam sebesar 1 persen maka akan menaikkan permintaan impor kopi bubuk Indonesia sebesar 0,352 persen.

Berbeda dengan India, karena India dengan Indonesia memiliki hubungan komplementer, maka nilai -0,041 pada elastisitas harga silang India dengan Indonesia menunjukkan bahwa ketika terjadi kenaikan harga kopi bubuk dari India sebesar 1 persen, maka akan menurunkan permintaan impor kopi bubuk Indonesia sebesar 0,041 persen. Begitupun sebaliknya, kopi bubuk Indonesia dengan India juga bersifat komplementer. Nilai -0,223 pada elastisitas harga silang Indonesia dengan India menunjukkan bahwa ketika terjadi kenaikan harga kopi bubuk Indonesia sebesar 1 persen, maka permintaan impor kopi bubuk India akan turun sebesar 0,223 persen.

Elastisitas harga silang diatas menunjukkan bahwa kopi biji Indonesia berkompetisi dengan kopi biji Vietnam dan India, sedangkan kopi bubuk Indonesia berkompetisi de- ngan Vietnam namun saling melengkapi dengan India. Dengan kata lain, Vietnam merupakan kompetitor Indonesia baik untuk kopi biji ataupun kopi bubuk.

Sensitifitas ekspor kopi Indonesia terhadap pengeluaran total impor kopi dilihat dari elastisitas pengeluaran yang ditunjukkan pada Tabel 7. Hasil tersebut menunjukkan bahwa elastisitas pengeluaran kopi biji Indonesia bernilai positif, namun elastisitas pengeluaran kopi bubuk Indonesia bernilai negatif.

Tabel 7. Hasil Elastisitas Pengeluaran Kopi Indonesia

\begin{tabular}{lcc}
\hline & \multicolumn{2}{c}{ Elastisitas Pendapatan } \\
\cline { 2 - 3 } & Kopi Biji & Kopi Bubuk \\
\hline Indonesia & 3,202 & $-1,514$ \\
Vietnam & 2,992 & 2,634 \\
India & $-2,315$ & $-0,621$ \\
\hline
\end{tabular}

Berdasarkan Tabel 7, nilai elastisitas pengeluaran kopi biji Indonesia dan Vietnam memiliki nilai elastisitas pengeluaran positif di Jerman, yaitu secara berturut-turut sebesar 3,202 dan 2,992. Nilai elastisitas pengeluaran tersebut berarti bahwa ketika terjadi penambahan pengeluaran untuk kopi bubuk di Jerman sebesar 1 persen maka akan meningkatkan permintaan kopi bubuk Indonesia sebesar 3,202 persen dan Vietnam sebesar 2,992. Namun karena elastisitas pengeluaran India di Jerman bertanda negatif, yaitu sebesar 3,202, maka ketika terjadi penambahan pengeluaran untuk kopi bubuk di Jerman sebesar 1 persen maka akan menurunkan permintaan kopi bubuk India sebesar 3,202 persen.

Nilai elastisitas pengeluaran kopi bubuk Indonesia dan India bertanda negatif, yaitu secara berturut-turut sebesar -1,514 dan -0,621, maka ketika terjadi penambahan pengeluaran untuk kopi bubuk di Jerman sebesar 1 persen maka akan menurunkan permintaan kopi bubuk Indonesia sebesar 1,514 persen dan kopi bubuk India sebesar 0,621. Sedangkan elastisitas pengeluaran kopi bubuk Vietnam di Jerman bernilai positif, maka ketika terjadi penambahan pengeluaran untuk kopi bubuk di Jerman sebesar 1 persen maka akan mening- 
katkan permintaan kopi bubuk Vietnam sebesar 2,634 persen.

Secara umum, permintaan impor kopi Jerman dari Indonesia dan negara eksportir utama lainnya lebih dipengaruhi oleh elastisitas harga sendiri daripada elastisitas harga silang dan pengeluaran. Hasil tersebut dapat dilihat dari nilai elastisitas permintaan yang menunjukkan bahwa nilai elastisitas harga sendiri lebih tinggi dibandingkan dengan kedua elastisitas lainnya. Sehingga dapat dikatakan bahwa banyak sedikitnya permintaan impor di suatu negara tergantung dengan kualitas dan jenis produk kopi yang dimiliki oleh negara produsen atau pengekspor.

Jenis kopi yang di ekspor ke Jerman mayoritas berupa kopi biji, daripada kopi bubuk. Namun sesuai dengan elastsitas silang kopi biji, harga Vietnam berpengaruh negatif terhadap harga Inodnesia. Efek negatif tersebut terjadi karena Indonesia dengan Vietnam sama-sama mengekspor kopi robusta dalam jumlah yang besar, sehingga Indnesia dengan Vietnam sama-sama berkompetisisi di pasar Jerman.

\section{KESIMPULAN DAN SARAN}

\section{KESIMPULAN}

1. Dinamika kebijakan perdagangan menunjukkan bahwa negara eksportir utama, termasuk Indonesia, cenderung memiliki tarif impor lebih rendah dibandingkan negara bukan pengekspor utama.

2. Permintaan impor kopi biji secara umum dipengaruhi oleh harga negara eksportir utama, namun permintaan impor kopi bubuk tidak dipengaruhi oleh harga negara importir utama. Kopi biji dan kopi bubuk Indonesia di pasar Jerman bersifat elastis, sedangkan kopi bubuk bersifat inelastis. Kopi Indonesia berkompetisisi dengan dengan Vietnam baik untuk kopi biji dan kopi bubuk. Kopi biji Indonesia bernilai positif dan kopi bubuk Indonesia bernilai negatif.

\section{SARAN}

Melihat posisi kopi Indonesia yang masih harus bersaing dengan kopi dari negara pengekspor utama lainnya, maka rekomendasi pada penelitian ini adalah

1. Melakukan perbaikan kualitas kopi. Penelitian ini tidak dibedakan antara data kopi robusta dan arabika, sehingga rekomendasi untuk penelitian selanjutnya adalah melakukan analisis dengan pemisahan jenis kopi arabika dan kopi robusta disetiap negara tersebut.

2. Analisis sebaiknya diperluas ke berbagai negara importir utama lainnya, seperti Amerika Serikat, Jepang, dan Malaysia yang kemudian dapat dibandingkan antar negara tersebut

\section{DAFTAR PUSTAKA}

[AEKI] Asosiasi Eksportir dan Industri Kopi Indonesia. 2014. Indonesia Coffee Market. Jakarta(ID): AEKI.

Baroh, Istis.et.al. 2014. Indonesian Coffee Competitiveness in the International Market: Armington Model Application. American Journal of Economics 4(4): 184194.

Chen, C., J. Yang, dan C. Findlay. 2008. Measuring the Effect of Food Safety Standards on China's Agricultural Exports. Review of World Economics. 144(1): 83-106.

Deaton, A dan Muellbauer, J. 1980. Economics and Consumer Behavior. Cambridge: Cambridge University

[DFID] Department for International Development. 2004. Rethinking tropical agricultural commodities. London: Department for International Development.

Drajat B, Agustian A, Supriatna A. 2007. Ekspor dan daya saing kopi bubuk Indonesia di pasar internasional : Implikasi strategis bagi pengembangan kopi bubuk organik. Jurnal Pelita Perkebunan 23(2):159-179. 
Eakins JM, Gallagher LA. 2003. Dynamic Almost Ideal Demand System: An Empirical Analysis of Alcohol Expenditure in Ireland. Applied Economics. 35(9):1025-1036.

Fortunika, Sevi Oktafiana. 2021. The Effect of Trade Policy on The Position of Indonesian Coffee Market among The Major Importing Countries. E3S Web of Conferences. 232(2021):1-12

Fugazza M. 2013. The Economics behind NonTariff Measures: Theoretical Insights and Empirical Evidence. Policy Issues in International Trade and Commodities Study Series. 57(1):1-20.

Galarraga, Ibon dan Anil Markandya. 2004. Economic Techniques to Estimate the Demand for Sustainable Products: A Case Study for Fair Trade and Organic Coffee in the United Kingdom. Jurnal Economia Agraria Recursos Naturales. 4,7 (2004): 109-134.

Gebrehiwot, Wolday dan Daloonpate, Apichart. 2012. Demand Analysis of Ethiopian Coffee in Japan. Kasetsart Journal 33:142-15.

[ICO] International Coffee Organization. 2018. Historical data on The Global Coffee Trade [Internet]. [Diunduh pada $21 \quad$ Agustus 2018]. http://www.ico.org/new_historical.asp.

Indonesia Eximbank Institute dan University Network for Indonesia Export Development (UNIED). 2019. Proyeksi Ekspor Berdasarkan Industri: Komoditas Unggulan. Jakarta (ID): Indonesia Eximbank.

[ITC] International Trade Center. 2019. Tarif Impor [Internet]. [Diunduh pada 13 Januari 2019]. http:/ / www.macmap.org.

Jamil, Ahmad Syaifudin. 2015. Analisis Permintaan Impor Garam Indonesia [Tesis]. Bogor: Institut Pertanian Bogor.

[Kemendag] Kementerian Perdagangan RI. 2015. Market Brief Produk Kopi (HS 0901) di Jerman. Atase Perdagangan
Kedutaan Besar Republik Indonesia Berlin. Berlin. Kemendag

[Kemenperin] Kementerian Perindustrian RI. 2015. Kebijakan Pengembangan Industri Pengolahan Kopi Nasional. Jakarta (ID): Kemenperin.

[Kementan] Kementerian Pertanian RI. 2015. Rencana Strategis Kementerian Pertanian Tahun 2015-2019. Jakarta (ID): Kementan.

[Kementan] Kementrian Pertanian RI. 2014. Market Intelligence: Kopi Andalan Ekspor Indonesia. Jurnal Pengolahan dan Pemasaran Hasil Pertanian. Jakarta(ID): Direktorat Jenderal Pengolahan dan Pemasaran Hasil Pertanian, Kementan

[Kementan] Kementrian Pertanian RI. 2017. Outlook 2017 Komoditas Pertanian Sub Sektor Perkebunan. Jakarta(ID): Kementan.

Li, Ming Huan dan Jung, Kun Oh. 2014. An Analysis of Coffee Demand System in Korea Using AIDS. Journal of the Korea Academia-Industrial Cooperation Society Vol. 15, No. 1 pp. 72-80. Hoseo University: Korea.

Nugroho A. 2014. The impact of food safety standard on Indonesia's coffee exports. Procedia Environmental Sciences. 20 (1): 425-433.

Purnamasari et al. 2014. Analisis daya saing kopi Indonesia di pasar dunia. Jurnal AGRISE 14(1): 58-66.

Rifin A. 2010. An Analysis of Indonesia's Palm Oil Position in The International Market. Oil Palm Industry Economic Journal 10(1): 35-42

Syaffendi M, Rifin A, Jahroh S. 2013. Dampak Penerapan Kuota Impor Terhadap Permintaan Karet Alam Indonesia oleh Negar China. Jurnal Agribisnis Indonesia 1(2): 125-142.

Sarirahayu, Kartika dan Aprianingsih, Kartika. 2018. Strategy to Improving Smallholder Coffee Farmers Productivity. The Asian Journal of Technology Management. 11(1): 1-9. 
Simanjuntak, Andreas Rumata. 2017. Permintaan Kayu Lapis Indonesia di Pasar Jepang Dengan Pendekatan An Almost Ideal Demand System (AIDS) [Tesis]. [Bogor(ID): Institut Pertanian Bogor.

Suherman, Tri. 2016. Analisis Permintaan Impor Minyak Kelapa Sawit Indonesia di Eropa 4 [Tesis]. Bogor(ID): Institut Pertanian Bogor.

[Trade Map] Trade statistics for international business development. 2018. Coffee Export Data [Internet]. [Diunduh pada 27 Juli 2018]. http://www.trademap.org/Index.aspx

[UN COMTRADE] United Nations International Trade Statistics Database. 2019. Nilai, Jumlah dan Harga Ekspor Kopi Indonesia, Brazil, Kolombia dan Vietnam di Jerman, Jepang dan Amerika Serikat 1996-2017. [Internet]. [Diunduh pada 13 Januari 2019]. http://www. comtrade.un.org.

[UNCTAD] United Nations Conference on Trade and Development. 2013. Non Tariff Measures to Trade: Economic and Policy Issues for Developing Countries. Geneva [Switzerland]: UNTAD.

Wan Y, Sun C, Grebner DL. 2010. Analysis of Import Demand forWooden Beds in the U.S. Journal ofAgricultural and Applied Economics. 42(4): 643-658.

[WB] Worldbank. 2019. Nilai Tukar Riil dan Gross Domestic Product [Internet]. [Diunduh pada 13 Januari 2019]. http://www. worldbank.org.

[WTO] World Trade Organization. 2019. NonTariff Measures: Sanitary \& Phytosanitary and Technical Barier to Trade [Internet]. [Diunduh pada 15 Januari 2019]. http://www.wto.org.

Yohannes, Michael Fesseha dan Toshinobu Matsuda. 2016. Weather Effects on Household Demand for Coffee and Tea in Japan. Agribusiness, an International Journal Vol. 32(1)33-44. Wiley Online Library: Japan 